\title{
Cypermethrin-Induced Alterations in Serum Calcium and Phosphate of Rats: Protective Role of Jamun Seed and Orange Peel Extracts
}

\author{
Babita D. Srivastava ${ }^{1}$, Manish Srivastava ${ }^{2}$, Sunil K. Srivastav ${ }^{1}$, Makoto Urata ${ }^{3,4}$, \\ Nobuo Suzuki ${ }^{4}$ and Ajai K. Srivastav ${ }^{1, *}$ \\ ${ }^{1}$ Department of Zoology, DDU Gorakhpur University, Gorakhpur 273009, India; ${ }^{2}$ Department of Chemistry, Digvijai Nath P.G. College, \\ Gorakhpur, India; ${ }^{3}$ Institute of Noto SATOUMI Education Research, Noto-cho, Ishikawa 927-0553, Japan; ${ }^{4}$ Noto Marine Laboratory, \\ Institute of Nature and Environmental Technology, Division of Marine Environmental Studies, Kanazawa University, Noto-cho, Ishikawa \\ 927-0553, Japan
}

Received: July 6, 2020; Revised: September 27, 2020; Accepted: October 4, 2020

\begin{abstract}
The present study investigated alterations in serum calcium and phosphate levels induced by cypermethrin (trade name Basathrin) exposure to rats and aimed to evaluate protecting role of jamun (Syzygium cumini) seed (JSE) and orange (Citrus sinensis) peel (OPE) extracts.

Wistar rats were treated as - Group A: Control; Group B: cypermethrin (CY); Group C: cypermethrin and jamun seed extract (CY+JSE); Group D: cypermethrin and orange peel extract (CY+OPE); Group E: orange peel extract (OPE); Group F: jamun seed extract (JSE). Cypermethrin dose was $25 \mathrm{mg} / \mathrm{kg}$ body wt/day whereas orange peel and jamun seed extract dose was $200 \mathrm{mg} / \mathrm{kg}$ body wt/day. Serum calcium and phosphate were analyzed after 15 days and 30 days following the treatment.

Serum calcium of rat treated with cypermethrin decreased after 15 and 30 days. In-group C, serum calcium decreased on day 15 and 30. In-group D serum calcium decreased at day 15 but on day 30 level increased. Calcium levels in-group C increased on day 15 and 30 as compared to group B. Moreover, levels in-group D is not significant on day 15 and 30.

In cypermethrin exposed rats, serum phosphate declined from day 15 to 30. In-group C, serum phosphate decreased at day15, which continued till day 30. Serum phosphate in-group D treated rats decreased on day 15 and 30. In groups E and F, there is no change in serum phosphate of rats on day 15; however, on day 30 levels decreased.

It can be concluded that cypermethrin treatment $(25 \mathrm{mg} / \mathrm{kg}$ body wt/day) caused alterations in the serum calcium and phosphate of the rats. The changes in these electrolytes could be protected by supplementation of extracts of jamun seed and orange peel at $200 \mathrm{mg} / \mathrm{kg}$ body wt/day. It is suggested that the cypermethrin exposed organisms should be given dietary supplement of these botanical extracts, which would reverse the toxic symptoms.
\end{abstract}

Keywords: Cyprmethrin; Serum calcium; Serum phosphate; Jamun seed; Orange peel

\section{Introduction}

Pests have always been a nuisance, and they damage crops in the field as well in stores. For the increased yield of crops, human beings use pesticides for the noxious arthropods and pests (Tripathi and Srivastav, 2010). Pesticides, being important for controlling injurious pests, also cause hazards to non-target organisms including humans (Bhusan et al., 2013; Chrustek et al., 2018; Tewari et al., 2018; Mahat et al., 2020). Pyrethroids have potent insecticidal properties and are potentially non-toxic to most non-target species, especially mammals. Cypermethrin is a non-systemic, light stable synthetic pyrethroid which is used mostly as residual treatment for the control of flies, ectoparasite infestation of animals, mosquitoes, cockroaches and for the control of range of insects on crops (Nair et al., 2011; Sharma et al., 2018; Mahat et al., 2020). The widespread use of cypermethrin caused several health hazards to non-target animals (including humans) such as toxicological alterations in liver and kidney (Grewal et al., 2010; Mossa et al., 2015; Bhusan et al., 2013; Das et al., 2017; Hamid et al., 2017; Srivastava et al., 2018), hematological (Saxena and Saxena, 2010; Das et al., 2017), genotoxic and neurotoxic effects (Sharma et al., 2014; Mhadhbi et al., 2020), generation of ROS (reactive oxygen species) (Yousef et al., 2019) and reproductive toxicity (Grewal et al., 2010; Das et al., 2017; Simon et al., 2018; Sharma et al., 2018; Singh et al., 2020; Zhang et al., 2020).

Phytonutrients/phytochemicals have been reported to be present in fruits, vegetables, spices and herbs. These phytochemicals have antioxidant properties as they scavenge free radicals (Mossa et al., 2015; Attia et al., 2017 a, b; Srivastava and Srivastav, 2017; Srivastava et al., 2018; Ahmed et al., 2019; Bashandy et al., 2019). Syzygium cumini (Jamun) has antidiabetic, antibacterial, antimalarial, free radical scavenging property, anti-

\footnotetext{
* Corresponding author e-mail: ajaiksrivastav@hotmail.com.
} 
ulcerogenic and anti-fertility activities (Nair et al., 2013; Kumari et al., 2017; Srivastava and Srivastav, 2017; Chagas et al., 2018; Srivastava et al., 2018). These properties of jamun have been attributed to antioxidant compounds present in jamun namely flavonoids, phenolic acids and anthocyanins (Raza et al., 2007; Srivastava and Srivastav, 2017; Srivastava et al., 2018). Orange (Citrus sinensis) also possess vitamin $\mathrm{C}$, flavonoids, acridone alkaloids, carotenoids, limonoids etc. (Hegazy and Ibrahim, 2012; Srivastava and Srivastav, 2017; Srivastava et al., 2018; Ahmed et al., 2019). Bashandy et al. (2019) reported that Citrus peel contain hespiridin which has antiinflammatory, antioxidant, anti-cancer and anti-lipedemic activities. Naringen and naringenin have been found in Citrus peels which have antimicrobial, antidiabetic and toxicity protecting activities (Ahmed et al., 2019).

Calcium, particularly its ionic form, plays a vital role in several physiological processes of vertebrates - hormone synthesis and release, neuronal excitability, blood clotting, cell adhesion, permeability of cell membranes to ions, muscle contraction, reproduction, etc. (Srivastav et al., 2008). These physiological processes are severely affected if there is a minor change in ionic calcium. Phosphate is required for intermediary metabolism (phosphorylated intermediates), genetic information (DNA and RNA), enzyme/protein components (phosphohistidine, phosphoserine), phospholipids and membrane structure (Norman and Litwack, 1987).

There exists no report regarding the protective effects of jamun seed extract and orange peel extract on the blood parameters (calcium and phosphate) in vertebrates. Therefore, the present study was aimed to investigate the changes in serum calcium and phosphate levels induced by cypermethrin exposure to male rats and to evaluate the possible protecting role of jamun (Syzygium cumini) seed and orange (Citrus sinensis) peel extracts.

\section{Materials and methods}

Male Wistar rats (115-130 g) were housed in polypropylene cages and acclimatized for 2 weeks in the laboratory under natural photoperiod (Light -11:46 to 12:08 hour) and provided standard laboratory feed and water ad libitum. Animal care and sacrifice were carried out according to the guidelines provided by Ethics Committee of the University.

The animals were randomly divided into six groups -A, B, C, D, E, and F, each consisting of 20 animals (5 rats per cage). During experiment, rats were maintained under natural photoperiod (Light -11:46 to 12:08 hour) and on the standard laboratory feed and water ad libitum. Dose of cypermethrin used in this study has been selected considering the doses used earlier by other investigators(i) $40-120 \mathrm{mg} / \mathrm{kg}$ b wt (Nair et al., 2011), (ii) $30 \mathrm{mg} / \mathrm{kg} b$ wt (Hamid et al., 2017 and (iii) 21.2-85 mg/kg b wt (Madu, 2015). The dose of jamun seed extract used in this study has been selected on the basis of doses used by earlier workers - (i) $250 \mathrm{mg} / \mathrm{kg}$ b wt (Behera et al., 2014), (ii) $200-800 \mathrm{mg} / \mathrm{kg} \mathrm{b}$ wt (Vihan and Brashier, 2017) and (iii) 200 and $400 \mathrm{mg} / \mathrm{kg}$ b wt (Kumar and Thakur, 2018). Dose of orange peel extract used in this study has been selected considering the doses used earlier by other investigators-(i) 125, 250 and $500 \mathrm{mg} / \mathrm{kg}$ b wt (Muhtadi et al., 2015), (ii) 100, 200 and $400 \mathrm{mg} / \mathrm{kg}$ b wt (Selmi et al., 2017) and $200 \mathrm{mg} / \mathrm{kg}$ b wt (Bashandy et al., 2019). Following treatments were given daily to these groups at 08:00 each day throughout the experiment:

- Group A: Control

- Group B: CY-treated: Rats received daily cypermethrin ( $25 \mathrm{mg} / \mathrm{kg}$ body wt)

- Group C: CY+JSE: These rats were given daily cypermethrin ( $25 \mathrm{mg} / \mathrm{kg}$ body wt) and jamun seed extract ( $200 \mathrm{mg} / \mathrm{kg}$ body wt) simultaneously

- Group D: CY+OPE: These rats were given daily cypermethrin ( $25 \mathrm{mg} / \mathrm{kg}$ body wt) and orange peel extract (200 mg/kg body wt) simultaneously

- Group E: OPE: Rats received daily orange peel extract ( $200 \mathrm{mg} / \mathrm{kg}$ body wt)

- Group F: JSE: Rats received daily jamun seed extract (200 mg/kg body wt)

Cypermethrin (trade name Basathrin) used in the present study was manufactured by BASF India Limited, Mumbai, India. Every day fresh cypermethrin dose was prepared. Jamun (Syzygium cumini) seeds were obtained from M/S SVM Naturals, Tamilnadu, India. Citrus sinensis fruits were obtained locally and peels were separated. Seeds and peels were thoroughly washed with water and dried at $40{ }^{\circ} \mathrm{C}$. The dried materials were powdered and mixed with ethanol (90\%) in 1:20 ratio (w/v) and kept on an orbital shaker for $48 \mathrm{~h}$. The solution was filtered with Whatman grade No.1 filter paper and filtrates were dried at $40{ }^{\circ} \mathrm{C}$. The dried residue was weighed and kept at $-20{ }^{\circ} \mathrm{C}$ for further use. For experiment, the residues were reconstituted with ethanol to provide desired dose to be given to rats (Srivastava et al., 2018).

Rats (from each group, under light ether anesthesia) were sacrificed $24 \mathrm{~h}$ after last dose on $15^{\text {th }}$ and $30^{\text {th }}$ day following the start of the experiment. Animals were fasted overnight before sacrifice. Blood samples ( $n=5$ from each group at each interval) were collected by cardiac puncture and allowed to clot at room temperature. Sera were separated and kept at $-20{ }^{\circ} \mathrm{C}$ until analyzed for serum calcium (Calcium kit, Sigma-Aldrich) and inorganic phosphate (Pointe Scientific, USA). Analysis was performed in duplicates for each sample.

Data are presented as mean \pm S.E. of five specimens. For multiple group comparisons, Two-way analysis of variance (ANOVA) was used. Differences between groups were determined by the post hoc Duncan test.

\section{Results}

Serum calcium level of cypermethrin (group B) treated rat exhibits a decrease after $15(\mathrm{P}<0.0001)$ and 30 day $(\mathrm{P}<$ $0.0001)$ (Fig. 1). In group $C$ (cypermethrin and JSE), the serum calcium level decreased on 15 day $(\mathrm{P}<0.0001)$ and on 30 day $(\mathrm{P}<0.014)$ as compared to group A. However, the levels at day 30 in group $C$ are slightly increased as compared to value of group $\mathrm{C}$ at day 15 . In group D $(\mathrm{CY}+\mathrm{OPE})$, the serum calcium level shows a decrease $(\mathrm{P}<$ 0.0006 ) at 15 day as compared to group A but on 30 day the level increases (not significant as compared to group A). The calcium levels in group $C$ is increased on day 15 $(\mathrm{P}<0.008)$ and day $30(\mathrm{P}<0.002)$ as compared to group $\mathrm{B}$. Moreover, the levels in group $\mathrm{D}$ are not significant on day 15 and day 30 as compared to group B This indicates that 
orange peel extract is not effective in recovering the decrease in calcium levels caused by cypermethrin. In group E (OPE) and group F (JSE), there is no change in serum calcium levels on 15 and 30 day. Analysis of Variance (ANOVA) indicates that the treatment is significant (15 day -- $\mathrm{F}=12.004, \mathrm{P}<0.0001 ; 30$ day $\mathrm{F}=2.658, \mathrm{P}<0.041$ ).

Serum phosphate levels of cypermethrin (group B) exposed rats decrease progressively from 15 day $(\mathrm{P}<$ 0.0008 ) to 30 day $(\mathrm{P}<0.0001)$ (Fig. 2). In group $\mathrm{C}$, the serum phosphate level displays a decline at 15 day (not significant) which continued till 30 day $(\mathrm{P}<0.0004)$. Serum phosphate levels in group $\mathrm{D}$ treated rats show decreased value on day $15(\mathrm{P}<0.009)$ and day $30(\mathrm{P}<$ $0.033)$. In group $E$ and group $F$, there is no change in serum phosphate levels of rats on day 15 as compared to control (group A); however, on day 30 the levels show significant decrease (group $\mathrm{E}(\mathrm{P}<0.04)$ as compared to group A. ANOVA indicates that the treatment is significant (15 day -- $\mathrm{F}=4.014, \mathrm{P}<0.006 ; 30$ day $\mathrm{F}=10.125, \mathrm{P}<0.0001)$.

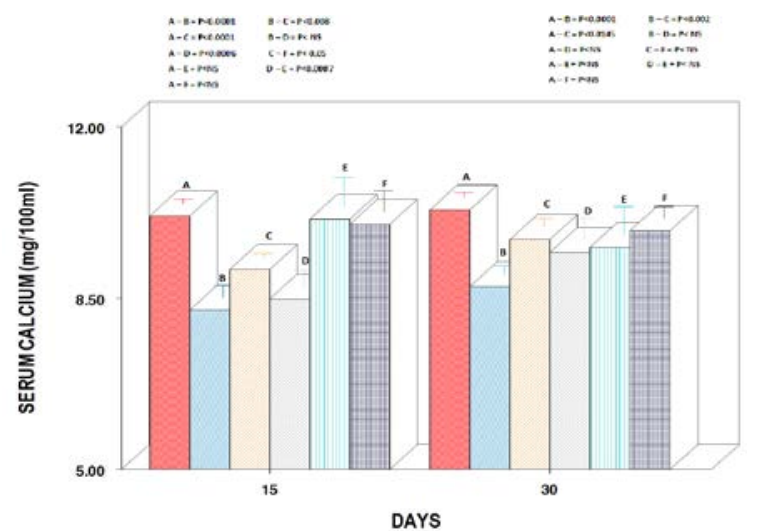

Figure 1: Serum calcium levels (mg/100 ml) of Wistar rat. Control ( $\square$, Group A), CY ( $\square$, Group B), CY+JSE $\square$, Group C), CY+OPE ( $\square$, Group D), OPE (而, Group E) or JSE (\#, Group F). All values indicate mean \pm SE of five specimens.

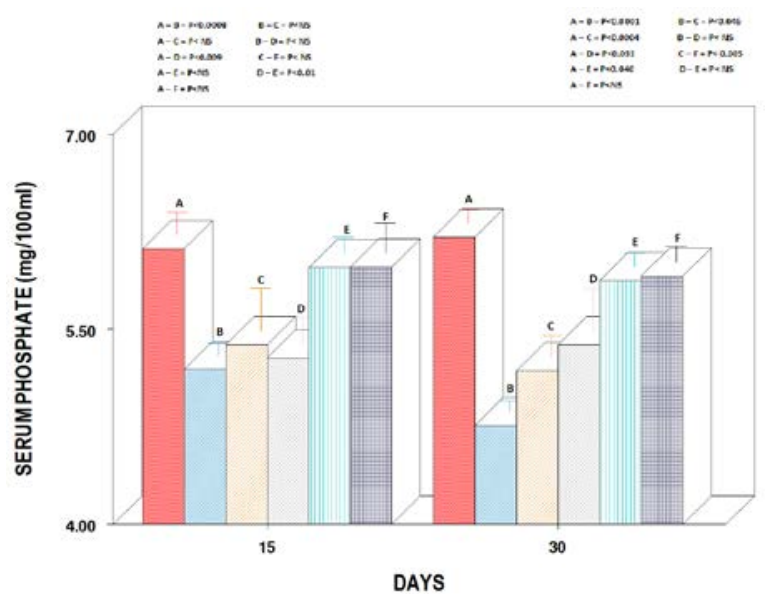

Figure 2: Serum phosphate levels (mg/100 ml) of Wistar rat. Control ( $\square$, Group A), CY ( $\square$, Group B), CY+JSE ( $\square$, Group C), CY+OPE ( $\square$, Group D), OPE ( $\square$, Group E) or JSE ( $\cong$, Group F). All values indicate mean \pm SE of five specimens.

\section{Discussion}

Cypermethrin treatment to rats provoked hypocalcemia. This is in agreement with the studies of earlier researchers who have observed hypocalcemia in rats after exposure to toxicants - mipcin (Rangoonwala et al., 2007), microcystin LR (Moreno et al., 2003), diazinon (Rangoonwala et al., 2005), heroin (Barai et al., 2009), heptachlor (Rangoonwala et al., 2004), cadmium (Tripathi and Srivastav, 2011) and chlorpyrifos (Tripathi et al. 2013). Agarwal et al. (2009) have reported hypocalcemia from chicken after exposure to gamma benzene hexachloride and quinalphos. Toxicants-induced hypocalcemia has also been reported from amphibian chlorpyrifos (Srivastav et al., 2018) and fish-- cadmium (Rai and Srivastav, 2003; Chowdhury et al., 2004), deltamethrin (Srivastav et al., 1997 b, 2010), cypermethrin (Mishra et al., 2010), malachite green (Srivastava et al., 1995), aldrin (Singh et al., 1996), formothion (Singh et al., 1997), botanical pesticides (Prasad et al., 2011 a, b; Kumar et al., $2011 \mathrm{a}, \mathrm{b}$ ), microcystin LR (Prakash et al., 2015, 2016) and combination of dimethoate, chlorpyrifos and malathion (Rani et al., 2017). Ghelichpour and Mirghaed (2019) have noticed an increase in plasma calcium levels after lufenuron and flonicamid exposure to common carp after $24 \mathrm{~h}$, however, with elongation of exposure the levels decrease. Andjelkovic et al. (2019) have recorded an insignificant decrease in serum calcium levels after exposure of cadmium to rats. In the present study, the calcium levels in group $\mathrm{C}$ are increased on day 15 and day 30 as compared to group B. This indicates that jamun seed extract is effective in recovering the calcium levels which were decreased by treatment with cypermethrin. Moreover, the levels in group D are not significant on day 15 and day 30 as compared to group B. This indicates that orange peel extract is not effective in recovering the decrease in calcium levels caused by cypermethrin.

Rats exposed to cypermethrin exhibited hypophosphatemia. Contradictory reports have been given by other investigators regarding the effects of toxicants on phosphate levels of rats - hypophosphatemia (microcystin - Moreno et al., 2003; cadmium --Tripathi and Srivastav, 2011 ; Andjelkovic et al., 2019; chlorpyrifos --Tripathi et al., 2013), hyperphosphatemia (heroin - Barai et al., 2009), intermittent effect (microcystin LR -Hooser et al., 1989) and no effect (mipcin -Rangoonwala et al., 2007; diazinon-- Rangoonwala et al., 2005; heptachlor-Rangoonwala et al., 2004). Several workers have noticed hypophosphatemia in fish after treatment with toxicants such as -- pyrethroids (deltamethrin, Srivastav et al., 1997 b; cypermethrin, Mishra et al., 2001), cadmium (Rai and Srivastav, 2003), organophosphate (chlorpyrifos, Srivastav et al., 1997 a), botanical pesticides (Kumar et al., 2011 a, b; Prasad et al., $2011 \mathrm{a}, \mathrm{b}$ ) and microcystin LR (Prakash et al., 2015, 2016). Ghelichpour and Mirghaed (2019) have recorded an initial increase in plasma phosphate levels after $24 \mathrm{~h}$ exposure of common carp to pesticide lufenuron and flonicamid. Later, these authors noticed a decrease in phosphate levels after elongation of exposure. The observed decrease in blood electrolytes of cypermethrin exposed rats could be attributed to the degeneration of kidney tubules (our unpublished work) 
which might have caused decreased reabsorption of these electrolytes.

\section{Conclusion}

It can be concluded that cypermethrin treatment at 25 $\mathrm{mg} / \mathrm{kg}$ body wt/day caused alterations in the serum calcium and phosphate of the rats. The changes in these electrolytes could be protected by supplementation of extracts of jamun seed and orange peel at $200 \mathrm{mg} / \mathrm{kg}$ body $\mathrm{wt} /$ day. It is suggested that the cypermethrin exposed organisms should be given dietary supplement of these botanical extracts which would reverse the toxic symptoms.

\section{Acknowledgments}

Ajai Kumar Srivastav is thankful to University Grants Commission, New Delhi, India for providing financial assistance for this study. The present study was also partly supported by the cooperative research program of the Institute of Nature and Environmental Technology, Kanazawa University, Japan (Accept No. 20007).

\section{References}

Agarwal S, Batra M and Chauhan S. 2009. Effects of gamma benzene hexachloride and quinalphos on serum calcium and phosphorus levels in experimentally fed broiler chickens. $J$ Immunology Immunopathol., 11: ISSN 0973-9149.

Ahmed OM, Fahim HI, Ahmed HY, Al-Muzafar HM, Ahmed RR, Amin KA, El-Nahass E and Abdelazeem WH. 2019. The preventive effects and the mechanisms of action of navel orange peel hydroethanolic extract, naringin, and naringenin in $\mathrm{N}$-acetylp-aminophenol-induced liver injury in Wistar rats. Oxidative Med Cellular Long., 2019: 2745352.

Andjelkovic M, Buha Djordjevic A, Antonijevic E, Antonijevic B, Stanic M, Kotur-Stevuljevic J, Spasojevic-Kalimanovska V, Jovanovic M, Boricic N, Wallace D and Bulat Z. 2019. Toxic effect of acute cadmium and lead exposure in rat blood, liver, and kidney. Int J Environ Res Public Health, 16: 274.

Attia YA, Hamed RS, Bovera F, Abd El-Hamid AE, Al-Harthi MA and Shahba HA. 2017a. Semen quality, antioxidant status and reproductive performance of rabbits bucks fed milk thistle seeds and rosemary leaves. Anim Reprod Sci., 184:178-186. doi: 10.1016/j.anireprosci.2017.07.014.

Attia YA, Al-Harthi MA and Hassan SS. 2017b. Turmeric (Curcuma longa Linn.) as a phytogenic growth promoter alternative for antibiotic and comparable to mannan oligosaccharides for broiler chicks. Rev Mex Cienc Pecu, 8 (1):1121.

Bashandy SAE, Ahmad-Farid OAH, Omara EA, El-Toumy SA and Salib JY. 2019. Protective effects of Citrus reticulata peel extract against potassium dichromate-induced reproductive toxicity in rats. Asian Pac J Reprod., 8: 267-275.

Barai SR, Suryawanshi SA and Pandey AK. 2009. Responses of parathyroid gland, C cells, and plasma calcium and inorganic phosphate levels in rat to sub-lethal heroin administration. $J$ Environ Biol., 30: 917-922.

Behera SR, Sckkizhar M and Babu KS. 2014. Hepatoprotective activity of aquous extract of Syzygium cumini seed on streptozotocin induced diabetes in rats. Inter J Ayurvedic Herbal Med., 4:1470-1477.
Bhusan B, Saxena PN and Saxena N. 2013. Biochemical and histological changes in rat liver caused by cypermethrin and betacyfluthrin. Arhiv za Higijenu Rada i Toksikologiju., 64: 57-67.

Chagas VT, Coelho RMRS, Gaspar RS, Silva SA, Mastrogiovanni M, Mendoca CJ, Ribeiro MNS, Paes AMA and Trostchansky A. 2018. Protective effects of a polyphenol-rich extract from Syzygium cumini (1.) skeels leaf on oxidative stress-induced diabetic rats. Oxidative Med Cellular Lon.,. 2018: Article ID 5386079.

Chowdhury MJ, Pane FF and Wood CM. 2004. Physiological effects of dietary cadmium acclimation and waterborne cadmium challenge in rainbow trout: respiratory, ionoregulatory, and stress parameters. Comp Biochem Physiol. C, 139: 163-173.

Chrustek A, Holynska-Iwan I, Dziembowska I, Bogusiewicz J, Wroblewski M, Cwynar A and Olszewska-Slonina D. 2018. Current research on the safety of pyrethroids used as insecticides. Medicina, 54: 61

Das T, Ghosh R, Paramanik A, Pradhan A, Dey SK, Roy T, Chatterjee D and Choudhary SM. 2017. Dose-dependent hematological, hepatic and gonadal toxicity of cypermethrin in Wistar rats. Toxicol Forensic Med., 2: 74-83.

Ghelichpour M and Mirghaed AT. 2019. Effects of sublethal exposure to new pesticides lufenuron and flonicamid on common carp, Cyprinus carpio, hydromineral balance to further saltwater exposure. Int J Aquat Bio., 7: 195-201.

Grewal KK, Sandhu GS, Kaur R, Brar RS and Sandhu HS. 2010. Toxic impacts of cypermethrin on behavior and histology of certain tissues of albino rats. Toxicol Intern., 17: 94-98.

Hamid MA, Moustafa N, Asran AEMAA and Mowafy L. 2017. Cypermethrin-induced histopathological, ultrastructural and biochemical changes in liver of albino rats: The protctive role of propolis and curcumin. Beni-Suef Univ J Basic Appl Sci., 6: 160173.

Hegazy AE and Ibrahim MI. 2012. Antioxidant activities of orange peel extract. World Appl Sci J., 18: 684-688.

Hooser SB. Beasley VR, Lovell RA, Carmichael WW and Haschek WM. 1989. Toxicity of microcystin-LR , a cyclic hepatopeptide hepatotoxin from Microcystis aeruginosa to rats and mice. Vet Pathol., 26: 246-252.

Kumar A, Prasad M, Mishra D, Srivastav SK and Srivastav Ajai K. 2011 a. Botanical pesticide, azadirachtin attenuates blood electrolytes of a freshwater fish Heteropneustes fossilis. Pest Biochem Physiol., 99: 170-173.

Kumar A, Prasad M, Mishra D, Srivastav SK and Srivastav Ajai K. 2011 b. Effects of Euphorbia tirucalli latex on blood electrolytes (calcium and phosphate) of a freshwater air-breathing catfish Heteropneustes fossilis. Toxicol Environ Chem., 93: 585592.

Kumar M and Thakur R. 2018. Syzygium cumini seed extract ameliorates arsenic-induced blood cell genotoxicity and hepatotoxicity in Wistar albino rats. Reports Biochem Molec Biol., 7:110-118.

Kumari B, Sharma V and Yadav S. 2017. The therapeutic potential of Syzygium cumini seeds in diabetes mellitus. J Med Plant Stud., 5: 212-218.

Madu EP. 2015. Teratogenic and embryotoxic effects of orally administered cypermethrin in pregnant albino rats. $J$ Toxicol Environ Hlth Sci., 7: 60-67.

Mahat S, Jha CB, Shrestha S and Koirala S. 2020. Effcets of vitamin $\mathrm{E}$ on cypermethrin induced toxicity in cerebral cortex of Wistar albino rats: A histological study. J Karnali Acad Health Sci., 3: 1-10.

Mhadhbi L, Khazri A, Sellami B, Dellali M, Mahmoudi E and Beyrem H. 2020. The protective effect of Hibiscus sabdariffa 
calyxes extract against cypermethrin induced oxidative stress in mice. Pesticide Biochem Physiol., 165: 104463.

Mishra D, Srivastav S, Srivastav SK and Srivastav Ajai K. 2001. Plasma calcium and inorganic phosphate levels of a freshwater catfish Heteropneustes fossilis in response to cypermethrin treatment. J Ecophysiol Occup Hlth., 1: 131-138.

Mishra D, Tripathi S, Srivastav SK, Nobuo S and Srivastav Ajai K. 2010. Corpuscles of Stannius of a teleost Heteropneustes fossilis following intoxication with a pyrethroid (cypermethrin). North-Western J Zool., 6: 203-208.

Moreno IM, Mate A, Repetto G, Vázquez CM and Cameán AM. 2003. Influence of microcystin-LR on the activity of membrane enzymes in rat intestinal mucosa. J Physiol Biochem., 59: 293300

Mossa AH, Ibrahim FM, Mohafrash SMM, Baker DHA and Gengaihi SE. 2015. Protective effect of ethanolic extract of grape pomace against the adverse effects of cypermethrin on weanling female rats. Evidence-Based Complem Alt Med., 2015: 381919. doi:10.1155/2015/381919

Muhtadi, Haryolo, Azizah T, Suhendi A and Yen KH. 2015. Antidiabetic and antihypercholesterolemic activities of Citrus sinensis peel: in vivo study. Nat J Physiol Pharma Pharmacol., 5: 382-385. doi: 10.5455/njppp.2015.5.2807201561

Nair LK, Begum M and Geetha S. 2013. In Vitro antioxidant activity of the seed and leaf extracts of Syzygium cumini. IOSR J Environ Sci Toxicol Food Technol., 7: 54-62.

Nair RR, Abraham MA, Lalithakunjamma CR and Nair ND. 2011. A pathomorphological study of the sublethal toxicity of cypermethrin in Sprague Dawley rats. Intern $J$ Nutrition Pharmacol Neurolo Diseases, 1:179-183.

Norman AW, Litwack G. 1987. Hormones. pp. 355-396, Academic Press Inc., New York.

Prakash C, Kumar A, Prasad M, Srivastav SK and Srivastav Ajai K. 2015. Microcystin-LR attenuates blood calcium and phosphate levels in stinging catfish Heteropneustes fossilis. Int J Pharm Bio Sci., 6: 1147- 1153.

Prakash C, Prasad M, Kumar A, Mishra D, Chaudhary A and Srivastav SK. 2016. Protective effect of $\mathrm{ZnCl}_{2}$ on toxicity produced by Microcystin-LR on serum calcium and phosphate levels of freshwater catfish Heteropneustes fossilis. Int J Pure App Biosci., 4: 111-117.

Prasad M, Kumar A, Mishra D, Srivastav SK and Srivastav Ajai K. 2011 a. Alterations in blood electrolytes of a freshwater catfish Heteropneustes fossilis in response to treatment with a botanical pesticide, Nerium indicum leaf extract. Fish Physiol Biochem., 37: 505-510.

Prasad M, Kumar A, Mishra D, Srivastav SK and Srivastav Ajai K. 2011 b. Blood electrolytes of a freshwater catfish Heteropneustes fossilis in response to treatment with a botanical pesticide, Euphorbia royleana latex. Integ Zool., 6: 150-156.

Rangoonwala SP, Suryawanshi SA and Pandey AK. 2007. Responses of serum calcium and inorganic phosphate levels as well as parathyroid gland and calcitonin producing $C$ cells of Rattus norvegicus to mipcin ad ministration. J Environ Biol., 28: 475-481.

Rangoonwala SP, Suryawanshi SA and Pandey AK. 2004. Responses of serum calcium and inorganic phosphate levels, parathyroid gland and C cells of Rattus norvegicus to heptachlor administration. J Environ. Biol., 25: 75-480.

Rangoonwala SP, Kazim M and Pandey AK. 2005. Effects of diazinin on serum calcium and inorganic phosphate levels as well as ultrastructures of parathyroid and calcitonin cells of Rattus norvegicus.. J Environ Biol., 26: 217-221.
Rai R and Srivastav Ajai K. 2003. Effects of cadmium on the plasma electrolytes of a freshwater fish Heteropneustes fossilis. $J$ Ecophysiol Occup Hlth., 3: 63-70.

Rani M, Gupta RK, Kumar S, Yadav J and Rani S. 2017. Pesticides' induces alterations in blood serum ions of Indian major carps. The Bioscan, 12: 847-850.

Raza A, Butt MS, Ul-Haq I and Suleria HAR. 2017. Jamun (Syzygium cumini) seed and fruit extract attenuate hyperglycemia in diabetic rats. Asian Pac J Trop Biomed., 7: 750-754.

Saxena P and Saxena AK. 2010. Cypermethrin induced biochemical alterations in the blood of Albino rats. Jordan J Biol Sci., 3: 111-114.

Selmi S, Rtibi K, Grami D, Sebai H and Marzonki L. 2017. Protective effects of orange (Citrus sinensis L.) peel aquous extract and hesperidin on oxidative stress and peptic ulcer induced by alcohol in rat. Lipids Hlth Disease, 16: 152.

Sharma A, Yadav B, Rohtagi S and Yadav B.,2018. Cypermethrin toxicity: A review. J Forensic Sci Criminal Invest., 9: 1-3

Sharma P, Firdous S and Singh R. 2014. Neurotoxic effect of cypermethrin and protective role of resveratrol in wistar rats. Intern. J Nutrition Pharmacol Neurol Diseases, 4: 104-111.

Simon U, David O, Peter R, Joseph R, Ijeoma C and Celestine N. 2018. Pathological effects of cypermethrin on the testes and accessory sexual glands of Yankasa rams. Arch Pathol Clinical Res., 2: 6-12.

Singh D, Irani D, Bhagat S and Vanage G. 2020. Cypermethrin exposure during perinatal period affects fetal development and impairs reproductive functions of $\mathrm{F} 1$ female rats. Sci Total Environ., 707: 135945. doi:10.1016/j.scitotenv.2019.135945

Singh NN, Das VK and Singh S. 1996. Effect of aldrin on carbohydrate, protein and ionic metabolism of a freshwater catfish, Heteropneustes fossilis. Bull Environ Contam Toxicol., 57: 204-210.

Singh NN, Das VK and Srivastava AK. 1997. Formothion and propoxur induced ionic imbalance and skeletal deformity in a catfish, Heteropneustes fossilis. J Environ Biol., 18: 357-363.

Srivastav Ajai K, Srivastav S, Srivastav SK and Suzuki N. 2018. Alterations in the serum electrolytes of the Indian skipper frog Euphlyctis cyanophlyctis caused by an organophosphate pesticide: chlorpyrifos. Jordan J Biol Sci., 11: 395-399.

Srivastav Ajai K, Srivastava SK and Srivastava AK. 1997 a. Response of serum calcium and inorganic phosphate of freshwater catfish, Heteropneustes fossilis, to chlorpyrifos. Bull Environ Contam Toxicol., 58: 915-921.

Srivastav Ajai K, Srivastava SK and Srivastav SK. 1997 b. Impact of deltamethrin on serum calcium and inorganic phosphate of freshwater catfish Heteropneustes fossilis. Bull Environ Contam Toxicol., 59: 841-846.

Srivastav Ajai K, Srivastava SK, Mishra D and Srivastav SK. 2010. Deltamethrin-induced alterations in serum calcium and prolactin cells of a freshwater teleost, Heteropneustes fossilis. Toxicol Environ Chem., 92: 1857-1864.

Srivastav Ajai K, Yadav S, Srivastav SK and Suzuki N. 2008. The ultimobranchial gland in poikilotherms: Morphological and functional aspects. In "Experimental Endocrinology and Reproductive Biology”, eds.: Haldar C, Singaravel M, PandiPerumal SR, Cardinali DP, Science Publishers, U.S.A. pp. 269296.

Srivastava BD and Srivastav Ajai K. 2017. Hepatoprotective effects of extracts of Syzygium cumini seeds and Citrus sinensis peels against microcystin LR-induced toxicity in rat. Intern $\mathrm{J}$ Zool Invest., 3: 95-105. 
Srivastava BD, Srivastava M, Srivastav SK, Suzuki N and Srivastav Ajai K. 2018. Cypermethrin-induced liver histopathology in rat: Protective role of jamun seed and orange peel extracts. Iranian J Toxicol., 12: 25-30.

Srivastava SJ, Singh ND, Srivastava AK and Sinha R. 1995 Acute toxicity of malachite green and its effect on certain blood parameters of a catfish Heteropneustes fossilis. Aquat Toxicol., 31: 241-247.

Tewari A, Banga HS and Gill JPS. 2018. Sublethal chronic effects of oral dietary exposure to deltamethrin in Swiss albino mice. Toxicol Indust Health, 34: 423-432.

Tripathi S and Srivastav Ajai K. 2010. Liver profile of rats after long-term ingestion of different doses of chlorpyrifos. Pesticide Biochem Physiol., 97: 60-65.

Tripathi S and Srivastav Ajai K. 2011. Alterations in the serum electrolytes, calcitonin cells and parathyroid gland of Wistar rat in response to administration of cadmium.. Proc. Intern. Con.
Environ. Pollution Remediation Ottawa, Ontario, Canada, 17-19 August 2011 Paper No. 126.

Tripathi S. Suzuki N and Srivastav Ajai K. 2013. Response of serum minerals (calcium, phosphate and magnesium) and endocrine glands (calcitonin cells and parathyroid gland) of Wistar rat after chlorpyrifos administration. Microscopy Res Technique, 76: 673-678.

Vihan S and Brashier DBS. 2017. A study to evaluate the antidiabetic effect of Syzygium cumini Linn. Seed extract in high fructose diet induced diabetes in albino rats. Int $J$ Basic Clin Pharmacol., 6: 1363-1366.

Yousef DM, El-Fatah SSA and Hegazy AA. 2019. Protective effect of ginger extract against alterations of rat thyroid structure induced by cypermethrin administration. J Exper Med Biol., 1: 19.

Zhang Y, Kong C, Chi H, Li J, Xing J, Wang F, Shao L and Zhai Q. 2020. Effect of a beta-cypermethrin and emamectin benzoate pesticide mixture on reproductive toxicity in male mice in a greenhouse environment. Toxicol Mech Methods, 30: 100-106. 